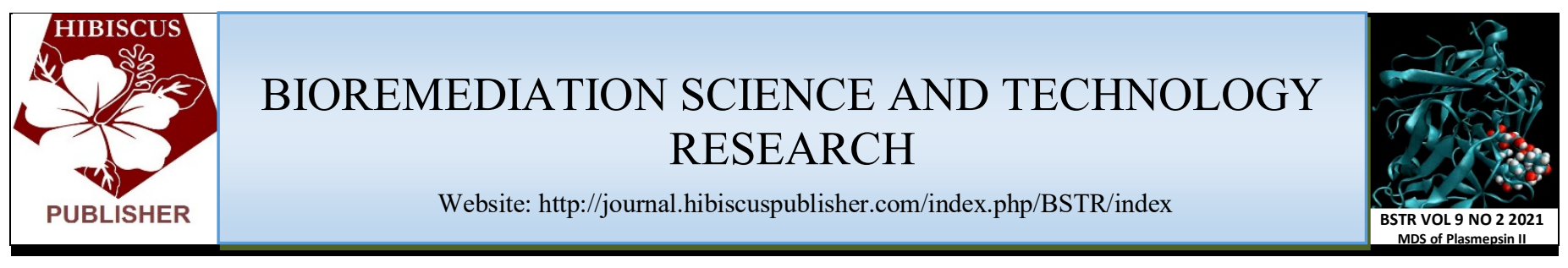

\title{
Characterization of Aniline Degradation by A Previously Isolated Molybdenum-reducing Pseudomonas sp.
}

\author{
Tijjani, A.U. ${ }^{1}$, Sufyan, A.J. ${ }^{1}$, Babandi, A. ${ }^{1}$, Ibrahim, S. ${ }^{1,2}$, Shehu, D. ${ }^{1}$, Ya'u, M. ${ }^{1}$, Babagana, K. ${ }^{1}$, Sani, I. ${ }^{3}$ and \\ H.M. Yakasai ${ }^{1 *}$
}

${ }^{1}$ Department of Biochemistry, Faculty of Basic Medical Sciences, College of Health Science,

Bayero University, Kano, P. M. B 3011, Nigeria.

${ }^{2}$ Centre for Biotechnology Research, Bayero University Kano P. M. B 3011, Nigeria.

${ }^{3}$ Kebbi State University of Science and Technology, Aliero, P. M. B 1144, Birnin Kebbi, Nigeria.

\author{
*Corresponding author: \\ Dr. H.M. Yakasai, \\ Department of Biochemistry, \\ Faculty of Basic Medical Sciences, \\ College of Health Science, \\ Bayero University, \\ Kano, P. M. B 3011, \\ Nigeria. \\ Email: hmyakasai.bch@buk.edu.ng
}

\begin{tabular}{l}
\hline HISTORY \\
Received: $23^{\text {rd }}$ Sep 2021 \\
Received in revised form: $4^{\text {th }}$ Nov 2021 \\
Accepted: $15^{\text {th }}$ Dec 2021 \\
\hline KEYWORDS \\
Pollution \\
Herbicide \\
Bacteria \\
Optimum condition \\
Detoxification
\end{tabular}

\begin{abstract}
Microorganisms play an integral role in detoxification and removal of toxic compounds from the environment. Aniline is the simplest aromatic amine, consisting of a phenyl group attached to an amino group that is used as herbicide to control weeds. Aniline is detrimental to both environment and health. In this research, six previously isolated bacteria (isolate A-F) were screened on Bushnell Hass media for their potential to grow and utilize aniline as a sole carbon source. Isolate A (Pseudomonas sp.) was found to tolerate and grow best with aniline sole source of carbon. Optimum conditions for aniline degradation by this isolate were found to be $\mathrm{pH} 6.0$, temperature between 30 and $37{ }^{\circ} \mathrm{C}$, inoculums size of $600 \mu \mathrm{L}$, aniline concentration of $200 \mathrm{mg} / \mathrm{L}$ and incubation time of $96 \mathrm{~h}$. The capacity of this isolate to reduce toxic aniline to less toxic form is novel and makes the bacterium important instrument for bioremediation of this pollutant.
\end{abstract}

\section{INTRODUCTION}

Environmental pollution rate has risen in the past few decades due to increased human activities on energy reservoirs, questionable agricultural practices and swift industrialization [1]. Aniline is an environmental pollutant that results from the manufacture of products such as dyes, additives, paints, plastics and herbicides [2,3]. Aniline is formed from the biotransformation of nitroaromatic compounds or other aniline based pesticides by microorganisms [4]. It is a toxic compound that causes oxidative stress and mechanisms that contributes to cell death [5]. It is a weak aromatic base that in alkaline condition remains stable and significantly affect aquatic lives [6]. Aniline is also an intermediate in the biodegradation of herbicide butachlor by Bacillus altitudinis [7].

The accumulation of these toxic substances in water bodies and soil has led to initiation of various research on ways to remove or eradicate the environments of these toxicants as the use of biological treatment has proven to be the most effective method of achieving this goal. However, high concentrations of destructive chemicals affects the ability of these organisms in the removal of the toxic compounds [8]. Fate of organic pollutants in the environment depends on the biochemical and physical aspects of the pollutants as well as its environment [9]. Nevertheless, suitable physical factors like $\mathrm{pH}$ and temperature as observed enhances the biodegrading ability of microorganisms [8]

Over the years, researchers have developed various techniques that can be used to rid environment of its pollutants, but to date, there is no single procedure that serve as a single-shot to remediating all type of pollutants [1]. Bioremediation as a process involves the use of microorganisms in the restoration of contaminated environment to their original form. The organisms residing in the polluted areas holds the key to removing pollutants [10]. Until present, literature on the isolation and characterization of aniline-degrading bacteria are scarce and often not from this region. Hence, this research will focus on finding indigenous isolate with potential to degrade aniline. 


\section{MATERIALS AND METHODS}

\section{Sample Collection and Reagents}

Aniline was a product of Sigma-Aldrich procured from the Department of Biochemistry, Bayero University, Kano state, Nigeria.

\section{Media Preparation}

All chemicals used in this research were of analytical grade. Bushnell Haas media containing $\left(\mathrm{gL}^{-1}\right): \mathrm{MgSO}_{4}, 0.2 ; \mathrm{CaCl}_{2}$, $0.02 ; \mathrm{KH}_{2} \mathrm{PO}_{4}, 1.0 ; \mathrm{K}_{2} \mathrm{HPO}_{4}, 1.0 ; \mathrm{NH}_{4} \mathrm{NO}_{3}, 1.0$ and $\mathrm{FeCl}_{3}, 0.050$ were added to $700 \mathrm{ml}$ of distilled water in a $1000 \mathrm{ml}$ conical flask and autoclaved at $121{ }^{\circ} \mathrm{C}$ for 45 minutes. $0.1 \mathrm{gL}^{-1}$ of aniline was added to the media to study aniline degradation by bacterial isolates. Nutrient broth was used for growth of bacterial culture.

\section{Screening of isolate for aniline degradation}

Screening of isolates was carried out in petri dish. In each plate, $20 \mathrm{ml}$ of prepared solid media was added under a lamina flow and allowed to solidify. To all the petri dish, bacterial isolates labelled (A-F) were inoculated and incubated for $72 \mathrm{~h}$. Screening for maximum growth was done macroscopically.

\section{Effect of Aniline Concentration}

Prepared liquid media (Bushnell Haas) was amended with different concentrations of aniline $(50,100,200,400,600,800$ $\mathrm{mg} / \mathrm{L}$ ) in $250 \mathrm{ml}$ conical flacks each was inoculated with $100 \mu \mathrm{L}$ of Pseudomonas sp. It was incubated at $37{ }^{\circ} \mathrm{C}$ in triplicate and also control without inoculums kept in triplicate and analysed for the growth of Pseudomonas sp. The optical densities were measured at $24 \mathrm{~h}$ intervals using spectrophotometer at wavelength of $(600 \mathrm{~nm})$.

\section{Effect of pH}

Prepared liquid media (Bushnell Haas) supplemented with 0.1 $\mathrm{g} / \mathrm{L}$ of aniline was adjusted to different initial $\mathrm{pH}(5.5,6.0,6.5$, 7.0, 7.5 and 8.0) using $\mathrm{HCl}$ and $\mathrm{NaOH}$. Each in triplicate was inoculated with $100 \mu \mathrm{L}$ of Pseudomonas sp. and incubated at 37 ${ }^{\circ} \mathrm{C}$, A triplicate control, without inoculation of Pseudomonas sp. was kept under similar conditions. The optical densities were determined at $24 \mathrm{~h}$ interval using a spectrophotometer at a wavelength of $600 \mathrm{~nm}$ to observe the growth rate of the isolate.

\section{Effect of Inoculums Size}

Prepared liquid media (Bushnell Haas) supplemented with 0.1 $\mathrm{g} / \mathrm{L}$ of aniline was inoculated with different inoculums sizes (100, $200,400,600,800$ and $1000 \mu \mathrm{L}$ ) each in triplicate, controls without inoculation were kept under similar condition. Optical density (OD) was measured using spectrophotometer at $600 \mathrm{~nm}$ at $24 \mathrm{~h}$ interval to determine the optimum inoculums size of the Pseudomonas sp. on aniline degradation.

\section{Effect of Temperature}

Prepared liquid media (Bushnell Haas) supplemented with $0.1 \mathrm{~g} / 1$ of aniline was inoculated with $100 \mu \mathrm{L}$ of Pseudomonas sp. and incubated at different temperatures $\left(25,30,37\right.$ and $\left.40{ }^{\circ} \mathrm{C}\right)$ in triplicate. Also controls, without inoculation of Pseudomonas sp. was kept under similar conditions. Optical densities (OD) were measured at $24 \mathrm{~h}$ interval using a spectrophotometer at $600 \mathrm{~nm}$ to determine the optimum growth temperature for aniline biodegradation.

\section{Effect of incubation Time}

Prepared liquid media (Bushnell Haas) supplemented with 0.1 $\mathrm{g} / \mathrm{L}$ of aniline was inoculated with $100 \mu \mathrm{L}$ of Pseudomonas sp. in triplicate. Also controls, without inoculation of Pseudomonas sp. was kept under similar conditions. Optical densities (OD) were measured at regular intervals of time $24 \mathrm{~h}$ up to $120 \mathrm{~h}$ using a spectrophotometer at $600 \mathrm{~nm}$ to determine the optimum growth temperature for aniline biodegradation.

\section{RESULTS}

\section{Screening of Isolates for Aniline Biodegradation}

A total of six (6) previously molybdenum-reducing bacteria isolated from Agricultural soils in Kano state were screened for their potential to degrade aniline and utilize it as sole source of carbon. Out of the six isolates, isolate A (Pseudomonas sp.) was observed to tolerate and grow best on Bushnell Haas media containing aniline as sole carbon source following $48 \mathrm{~h}$ of incubation at $37^{\circ} \mathrm{C}$, thus was chosen as a better candidate for further analysis.

\section{Characterization of Aniline Degradation}

\section{Effect of incubation time on aniline degradation}

The result of the effect of incubation time shows that Pseudomonas sp. was found to grow exponentially attaining optimum after $96 \mathrm{~h}$ of incubation, while a decline in growth was observed beyond the optimum incubation time, signifying its death phase (Fig 1).

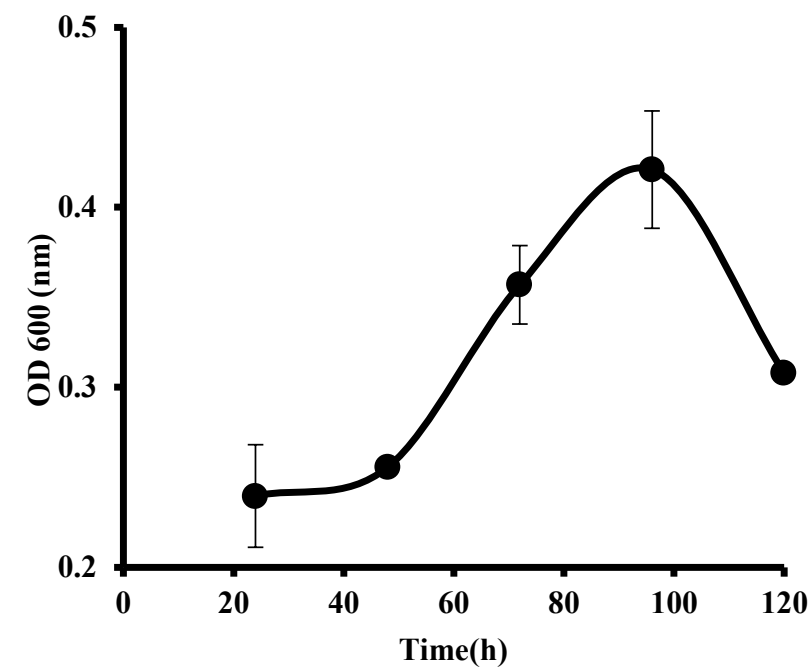

Fig. 1. Effect of incubation time on aniline degradation by Pseudomonas sp. Data represent: Mean \pm standard deviation of triplicate determination.

\section{Effect of Aniline Concentration}

The effect of aniline concentrations on the degradation capability of Pseudomonas sp. was assessed between $50-800 \mathrm{mg} / \mathrm{L}$. An optimum growth was observed at $200 \mathrm{mg} / \mathrm{L}$ concentration, with a sharp decline in growth observed as the concentration was increased between 400 to $600 \mathrm{mg} / \mathrm{L}$ after $48 \mathrm{~h}$ of incubation (Fig. 2). 


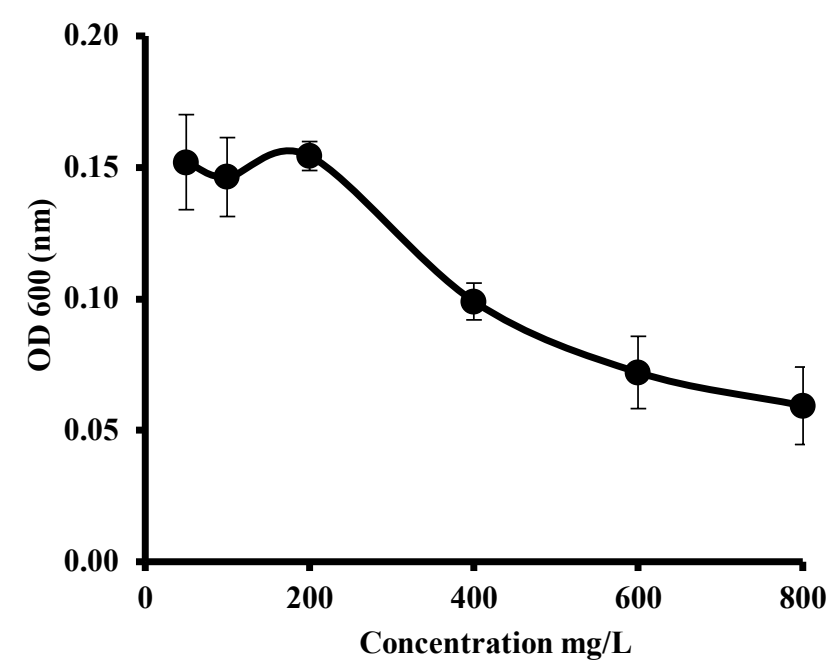

Fig. 2. Effect of aniline Concentrations (carbon source) on aniline degradation by Pseudomonas sp. after $48 \mathrm{~h}$ of incubation. Data represent mean \pm standard deviation of a triplicate concentration.

\section{Effect of $\mathrm{pH}$ on Aniline degradations}

The effect of various initial $\mathrm{pH}$ on Aniline degradations was evaluated at different initial $\mathrm{pH}$ range from $5.5-8.0$. The result obtained showed that the growth was found to be optimum at $\mathrm{pH}$ 6.0 for aniline degradation. However, growth decreases significantly $(\mathrm{p}<0.05)$ at $\mathrm{pH}$ above 6.0 over $96 \mathrm{~h}$ of incubation (Fig. 3).

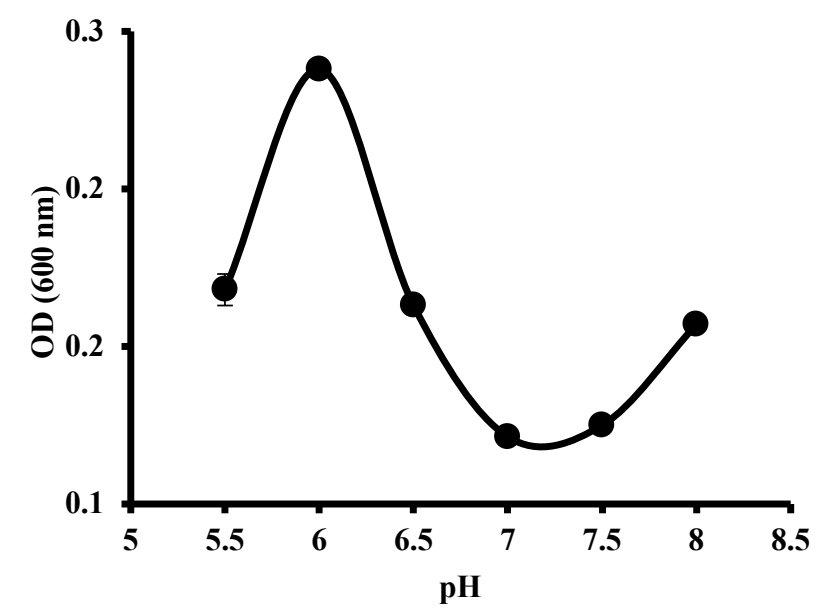

Fig. 3. Effect of various initial $\mathrm{pH}$ on aniline degradation by Pseudomonas sp. after $96 \mathrm{~h}$ Incubation Data represent: Mean \pm Standard Deviation of triplicate determination.

\section{Effect of inoculums size on aniline degradation}

Inoculums of $100-1000 \mu \mathrm{L}$ were used to determine the effect of inoculums sizes. The result showed that the growth increases as size of the inoculum increases (Fig. 4). Though the increase in growth was insignificant ( $p>0.05$ ) from $600-1000 \mu \mathrm{L}$.

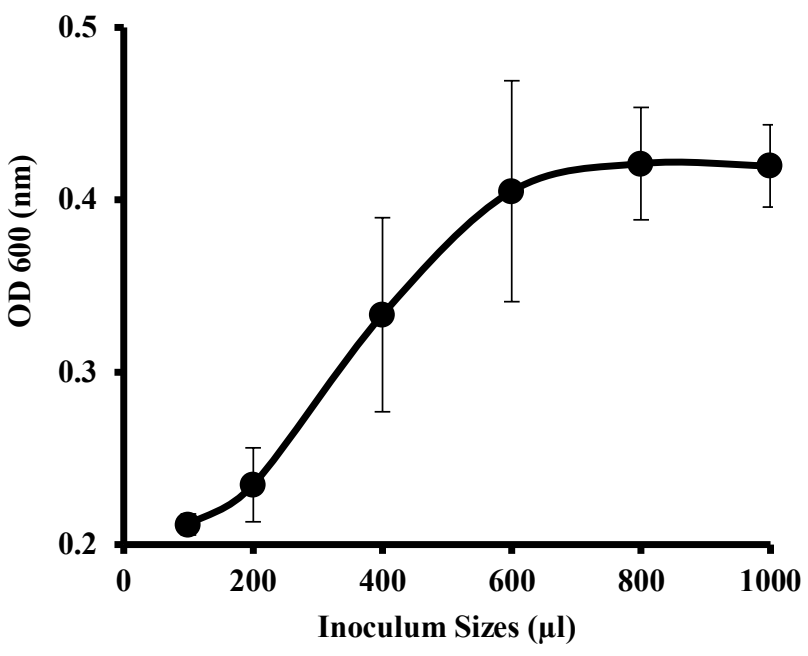

Fig. 4. Effect of inoculums sizes on aniline degradation by Pseudomonas sp. after $96 \mathrm{~h}$ of incubation. Data represent: mean \pm standard deviation of triplicate determination.

\section{Effect of temperature on Aniline degradation}

The effect of temperatures on aniline degradation by Pseudomonas sp. was assessed ranging from 25 to $40{ }^{\circ} \mathrm{C}$. Optimum growth was seen at $37^{\circ} \mathrm{C}$, though insignificantly $(p>0.05)$ vary from $30{ }^{\circ} \mathrm{C}$, providing wide range of optimum temperature to be between 30 and $37^{\circ} \mathrm{C}$ (Fig. 5).

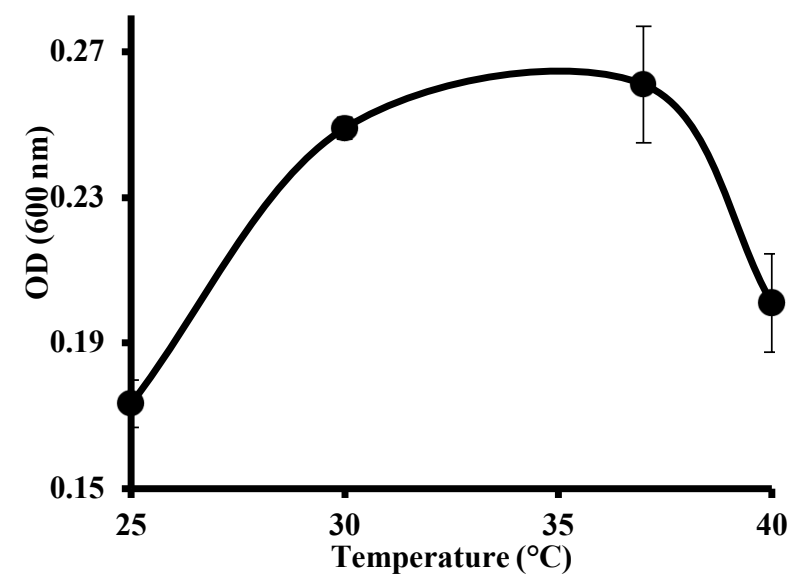

Fig. 5. Effect of temperature on aniline degradation by Pseudomonas $\mathrm{sp}$ Data represent: mean \pm standard deviation of triplicate determination.

\section{DISCUSSION}

Bioremediation taps into the ability of microorganisms to metabolize and convert organic contaminants into less toxic form. It has been an efficient method, economic and environmentally friendly biological treatment technique [11]. In the present study, different concentrations were used to determine the tolerance of the bacterium to aniline. 
The result revealed a lower optimum concentration of $200 \mathrm{mg} / \mathrm{L}$, compared to other literature. [2] reported a tolerable concentration by Enterobacter ludwigii KH-5 of up to $700 \mathrm{mg} / \mathrm{L}$. [12] reported a concentration of $2000 \mathrm{mg} / \mathrm{L}$ degraded in $22 \mathrm{~h}$ by Delftia sp. XYJ6. [13] reported an optimum concentration of $3200 \mathrm{mg} / \mathrm{L}$ by Delftia tsuruhatensis $14 \mathrm{~S}$. [14] also reported an off-the-chart tolerable concentration of up to $5000 \mathrm{mg} / \mathrm{L}$. Considering some of these findings, it can be safe to say, despite the fact that this isolate tolerated and utilize aniline as sole carbon source, but it is less efficient degrader of the toxicant compared to Delftia sp. strains.

In another study set to test the effect of $\mathrm{pH}$ on the degradation potential of this bacterium, a $\mathrm{pH}$ of 6.0 was found to be optimum. This means that the bacterium is likely to be an acidophile. The findings contradict the work on Rhodococcus erythropolis AN-13 with an optimum $\mathrm{pH}$ between 5.0 to 9.0 [15]. Additionally, growth of the bacterium in the media was observed to increase as the inoculum sizes increases attaining maximum growth at $600 \mu \mathrm{L}$, from which a steady state was maintained. This can be explained looking at the fact that a larger healthy inoculum multiplies exponentially much better than small inoculum.

Temperature exerts a strong selective pressure on microbial communities and can affect the degradation of organic compounds through direct effects on enzyme activity [16]. Optimum temperature was observed in this study to between 30 and $37{ }^{\circ} \mathrm{C}$. A similar study on the degradation of aniline by Pseudomonas strain $\mathrm{KI}$ reported $30^{\circ} \mathrm{C}$ optimum temperature for biodegradation [17]. It was also demonstrated in another study that growth and metabolic activity of Pseudomonas sp. B10 was also best at $30^{\circ} \mathrm{C}$ hence effective for degradation [18].

\section{CONCLUSION}

In this study, the potentials of a previously isolated molybdenum reducer to degrade aniline was determined. The bacterium was found to grow optimally at $\mathrm{pH} 6.0$, temperature $37^{\circ} \mathrm{C}$, incubation time of $96 \mathrm{~h}$ and aniline concentration of up to $200 \mathrm{mg} / \mathrm{L}$ with inoculums size of $600 \mu \mathrm{l}$. Hence this isolate could be suitable organism for the future bioremediation of this pollutant.

\section{REFERENCES}

1. Azubuike CC, Chikere CB, Okpokwasili GC. Bioremediation techniques-classification based on site of application: principles, advantages, limitations and prospects. World J Microbiol Biotechnol. 2016;32(11).

2. Kafilzadeh F, Khezri A. Biodegradation of aniline by Enterobacter ludwigii kh-5 isolated from the soil around shiraz refinery, Iran. Global NEST J, 2016;18(X):1-11.

3. Yen J-H, Tsai P-W, Chen W-C, Wang Y-S. Fate of anilide and aniline herbicides in plant-materials-amended soils. J Environ Sci Heal Part B. 2008 Jun;43(5):382-9.

4. Mujahid M, Sasikala C, Ramana VC. Aniline is an inducer, and not a precursor, for indole derivatives in Rubrivivax benzoatilyticus JA2. PLoS One. 2014;9(2):1-10.

5. Wang Y, Gao H, Na X, Dong S, Dong H, Yu J, et al. Aniline Induces Oxidative Stress and Apoptosis of Primary Cultured Hepatocytes. Int J Environ Res Public Health, 2016;5-7.

6. Sarwade V, Gawai K. Biodegradation of aniline by alkaliphilic strain Bacillus badius D1. IOSR J Environ Sci Toxicol Food Technol, 2014;8(5):71-8.

7. Kaur R, Goyal D. Biodegradation of Butachlor by Bacillus altitudinis and Identification of Metabolites. Curr Microbiol, 2020;76:2602-2612.

8. Khan SA, Hamayun M, Khan AL, Ahmad B, Lee I. Influence of pH , temperature and glucose on biodegradation of 4-aminophenol by a novel bacterial. Afr J Biotechnol, 2009;8(16):3827-31.
9. Boyd SA, Shelton DR, Berry D, Tiedje JM. Anaerobic Biodegradation of Phenolic Compounds in Digested Sludge. Appl Environ Microbiol, 1983;46(1):50-4.

10. Verma JP, Jaiswal DK. Book Review: Advances in Biodegradation and Bioremediation of Industrial Waste. Front Microbiol. 2016;6(January):2.

11. Feidieker D, Kampfer P, Dott W. Microbiological and chemical evaluation of a site contaminated with chlorinated aromatic compounds and hexachlorocyclohexanes. FEMS Microbiol Ecol,1994;15: 265-78.

12. Chengbin X, Jun N, Hai YAN, Xudong SUN. Biodegradation of Aniline by a Newly Isolated Delftia sp. XYJ6. Chin J Chem Eng, 2009;17(3):500-5.

13. Sheludchenko MS, Kolomytseva MP, Travkin VM, Akimov VN, Golovleva LA. Degradation of Aniline by Delftia tsuruhatensis 14S in Batch and Continuous Processes. Appl Biochem Microbiol. 2005;41(5):465-8.

14. Liu Z, Yang H, Huang Z, Zhou P, Liu S-J. Degradation of aniline by newly isolated, extremely aniline-tolerant Delftia sp. AN3. Appl Microbiol Biotechnol. 2002;58(5):679-82.

15. Aoki K, Ohtsuka K, Shinke R, Nishira H. Isolation of Anilineassimilating Bacteria and Physiological Characterization of Aniline Biodegradation in Rhodococcus erythropolis AN-13. Agr Biol Chem, 2014;1369.

16. Pettersson M, Baath E. Temperature-dependent changes in the soil bacterial community in limed and unlimed soil. FEMS Microbiol Ecol, 2003;45: 13-21.

17. Knight D, Turco RF. Characterization of a Pseudomonas sp. Capable of Aniline Degradation in the Presence of Secondary Carbon Sourcest Df. Appl Environ Microbiol, 1989;55(2):385-9.

18. El-Deeb BA. Plasmid-Mediated Aniline Assimilation by Pseudomonas sp. B10. J Microbial Biotech, 2001; 11(1):79-84. 